\title{
GESER IN ENGLISH: A SHORT HISTORY OF TRANSLATION
}

\begin{abstract}
In 1995 to mark the thousand-year anniversary of the Buryat Geser, the Kray Gesera (Land of Geser) ethnographic park was opened in the Okinskiy region of Buryatia. At the opening ceremony, the American Daniel Plumley [1996: 20-21], who had played an integral part in the park's creation, was compelled to admit that he knew almost nothing about the figure of Geser. He just could not find anything about him "in European books". As we celebrate another anniversary for Geser in 2020 , one must ask whether much has changed during this past quarter century in which the rise of the internet has revolutionised study by granting access to all manner of texts once obscure and difficult to obtain. In this paper I undertake a short survey of what there is now readily available on the Mongolic Geser in English, both forgotten gems and new exciting treasures.
\end{abstract}

Keywords: Geser, English Language, Jeremiah Curtin, Igor de Rachewiltz, Yelivaveta Khundaeva.

\section{The 1716 Geser}

In 1839 Isaak Jakob Schmidt famously began the European study of Geser by publishing a German translation of the seven-chapter Mongol-script Geser text that had been printed in Beijing in 1716. Today, however, very few people are aware that in 1927 American Ida Zeitlin [2003] took it upon himself to translate Schmidt's text into English under the title Gessar Khan: A Legend of Tibet. Zeitlin's work has been reprinted a number of times over the years, including in a 1991 "retold" version titled Gesar!

Zeitlin had no knowledge of Mongolian, so where Schmidt makes an assumption or error, Zeitlin simply copies it. He also sometimes leaves out large parts of the story for no discernible reason. However, one glaring thing that Zeitlin does not seem to understand about the 1716 text is that much of it is supposed to be funny. It has a very dark, violent and earthy sense of humour. As Mongolist Igor de Rachewiltz [2017: 17] writes: "While the seven chapters of [Geser] are suffused with Lamaist culture, this is not the predominant influence in the Mongolian narrative, which relies more on the profane, entertaining value of semicomic human-like situations, flavoured with tricks, deception, magic and picaresque interludes, the emphasis being on the bizarre, unusual, and unexpected."

Zeitlin also often chooses to insert a great deal of awkward, antique figures of speech into his translation. Cows are "kine", enemies are "knaves", and everyone is a "thou" or "ye". Opening the text at random, I immediately run into Geser's wife Rogmo crying out "For shame, ye maidens!" There is such a thing as trying to give a modern translation an "epic" feel, but this can become a little too artificial, even silly, if one isn't careful.

In the mid-2010s Igor de Rachewiltz began work on the first full English translation of the 1716 Geser. As with his landmark translations of The Secret History of the Mongols, his aim was to keep as closely as possible to the text while also making it eminently readable. Sadly, de Rachewiltz passed away in mid-2016, having only completed a translation of the first of the seven chapters. This first chapter was published online by ANU press in 2017 under the title Joro's Youth. It was de Rachewiltz's wish that Joro's Youth be put up for free download online. His philosophy was that the wealth of Mongolian literature, often prohibitively expensive and difficult to procure, should be available to everyone.

When I have had the time the past few years, I have been attempting to finish the English translation of the other six chapters of the 1716 Geser that de Rachewiltz started. In doing this I have tried as closely as I can to retain the translation choices de Rachewiltz established in chapter one. At present, only a little revision remains to be done before it will be ready to publish. I have also started work on some of the "additional" chapters of the Mongol Script Geser corpus not found in the 1716 text. However, it may be a little while before I am able to complete all of these. As Igor de Rachewiltz said to me one day while we were discussing Geser: "there is simply never enough time. There is never enough time just to study."

\section{The Buryat Geser}

The cornerstone to Buryat Geser studies and the establishment of the epic's millennial dating is of course the version told by reciter Manshuud Emegeev to pioneering scholar Tsyben Zhamtsarano in 1906 [Zhamtsarano 1930-31]. Manshuud's Abai Geser Khübüün is very different from all other Buryat, let alone 
other Mongolic or Tibetan versions of the epic ever recorded. Rather than being about cosmic battles between khans and armies it is about a seemingly primordial world of warring families of heroes and mangadkhai monsters.

As a result of this, Manshuud's version of Geser seems strangely unique. However, there does exist another version of Manshuud's Geser, one in English that was taken down by another folklorist, the American Jeremiah Curtin in 1900, and published posthumously in his 1909 book A Journey to Southern Siberia. Several Russian Geser-scholars are aware of the existence of this text and reference it from time to time [Sharakshinova 1969: 37-8, 139; Neklyudov 1984: 211], but little in-depth comparative work seems to have been done as of yet. Journey is today easily accessible for free online through the website archive.org.

The version of Geser that Zhamtsarano took down from Manshuud is actually a cycle of three interrelated stories: those of Geser and his sons Oshor Bogdo and Khürin Altai Khübüün. To Curtin Manshuud also told another, different, three-part Geser cycle. The first part is about Geser, and the second his son Ashir Bogda. However, the third part tells the story of a man called the Iron Hero. This character is first introduced in the Geser story as having been fashioned out of iron by the heavenly smiths of the Tenger gods to save Geser when he is transformed into a horse by an evil monster [Curtin 1909: 158-163]. He does not appear in Zhamtsarano's version at all. The closest parallel we might find to him is when the heavenly smiths rebuild Geser's own body with iron after he fights the monster Galkha Nurman [Zamtsarano 1930: lines 4465ff].

As an improvisational oral storyteller Manshuud could easily create and change the plots for stories. Manshuud's two different Geser cycles are typical of Mongolic oral epics in that they are, as Rinchindorji [2001: 389] calls them, "chain epics", in which common plotlines and poetic formulae are bolted together to produce "new" stories. This becomes even more obvious when we read the ten other stories that Curtin [1909: 186-300] includes from Manshuud: two very different versions of the story of the hero Buruldai Bogdo, Hunkuvai, Varhan Tulai Hubun, Altin Shagai, Yerente Khaan and his Son Sogto, Alamaldjin and his Twin Sister Hanhai, and the story of the twin boys Altin Shagai and Mungen Shagai. Yerente Khaan is the same story as Yirensei, which Zhamtsarano took down from Manshuud in 1905 and published in 1914. For the most part Curtin's version follows the plot of the latter very closely.

Manshuud's epics primarily concern heroes fighting monsters and winning brides by having to complete dangerous challenges set by potential fathers-in-law. Again and again Manshuud's heroes are charged to chain up a yellow dog [Curtin 1909: 244, 254. 267-8, 294; Zhamtsarano 1914: line 7780f, 1930-31: lines 17900-18010], or retrieve the feathers of the divine bird Kherdig (Garuda) [Curtin 1909: 149, 282-5; Zhamtsarano 1914: lines 8260f, 1930-31: lines 5150-5300, 19450-20524].

Manshuud's heroes go about their quests within the confines of a small epic "cosmos" in which the heroes always meet with the same geographical markers, such as a world-mountain with a world-tree atop it and hordes of skeletons below needing to be revived by the mountain's magical spring [Curtin 1909: 149, 155, 158193-4, 211,221,234, 240-1, 251, 262, 275, 282, 294; Zhamtsarano 1930-31: lines 10670-960, 14425789, 16305-370]. Heroes meet with and kill the same generic mangadkhai monster, whether called Dan'yal Shara [Zhamtsarano 1914: 776f, 1930-31: lines 9390-984, 14881-15370, 18915-20430] or Zuudag Shara [Zhamtsarano 1930-31: lines 7098-210, 12665-13879, 18126-20430; Khomonov 1972: lines 1123f]. The worst punishment for monsters and treacherous relatives is always being nailed to a tree [Curtin 1909: 21920, 231, 299; Zhamtsarano 1914: 3060-100, 3282-335, 1930-31: 7180-200, 10250-264]. With this we realise that while Manshuud's Geser might seem unique compared with other Buryat variants, compared with Manshuud's other stories it is not particularly unique at all.

Moreover, there are elements of the Geser tradition that find their way into Manshuud's other non-Geser stories. For instance, Geser's scheming uncle Chotong, does not appear in either version of Manshuud's Geser. However, he does appear as the evil uncle Zotan in the story Altin Shagai [Curtin 1909: 271-2]. Similarly, in the story of Khaa Oshir Khübü̈n that Zhamtsarano recorded from reciter Yolbon Shalbagai in 1903 we even find him transformed into a pair of evil uncles called Khara and Shara Zutan [Zhamtsarano 1913: lines 340f; Shoolbraid 1974: 33]. One might note here that there apparently exists an English translation of this latter story by Rudnev [1924], but it remains almost impossible to find a copy. Greater engagement with the Curtin material by scholars far more knowledgeable than myself about Buryat epic may bring to light far more interesting parallels and repetitions.

Increasing exchange towards the English-speaking world is also now possible thanks to Buryat scholar Yelizaveta Khundaeva's 2017 English translation of the first third of Manshuud's 1906 Geser cycle under the title The Buryat Heroic Epic 'Geser'. Published as an eBook through Kindle, the text also includes a dozen or so short essays by Khundaeva on diverse and fascinating subjects such as Buryat religious cults and 
rituals, a comparison between Geser and the Anglo-Saxon Beowulf, and the ways in which the syllabary of the epics partakes in the mathematical proportion known as phi, or the "golden mean". Even the immense value of Khundaeva's translation aside, these essays render accessible Russian-language Buryat Geserstudies to the English-speaking world for the first time.

As with de Rachewiltz's Joro's Youth, Khundaeva's decision to publish The Buryat Heroic Epic as an eBook online rather than through academic publishers usually pitched only at university libraries, means that a global audience can now readily have access to an amazing milestone in Geser-studies. Within a couple of clicks one can now have both of Manshuud's versions of Geser in English at one's fingertips. For the $1025^{\text {th }}$ anniversary of Geser the translation is also being released as a "hard copy" book.

This said, I think I will finish with a personal story concerning the vital role played by the internet in introducing myself to Geser. Back in 2003, when I was fifteen, I first came across the Buryat Geser through American Sarangerel Odigan's (Julie Anne Stewart's), translation of an unspecified Unga Geser variant, The Epic of King Gesar on her website buryatmongol.org. Had it not been for Sarangerel's site, I do not think I would have ever ended up writing a PhD thesis on the Buryat Geser, which is soon to become a book. Nor would I now be translating the 1716 Geser. In bringing to light and celebrating the value of resources such as this, I hope that others too might discover the Mongolic Geser traditions and derive as much fascination and joy from them as I have.

\section{Bibliography}

Curtin, J. A Journey to Southern Siberia: The Mongols, their Religion and their Myths, Little, Brown, Boston, 1909. https://archive.org/details/journeyinsouther00curt

De Rachewiltz I. and Li N. Joro's Youth: The First Part of the Epic of Geser Khan. Canberra, 2017. https://press.anu.edu.au/publications/joros-youth

Khomomov M. P. Bukha Khara Khubun: Uligery, zap. Ts. Zh. Zhamtsarano. Ulan-Ude, 1972.

Khundaeva Ye. O. Geser: The Buryat Heroic Epic. Ridero Smart Publishing System, eBook, 2017.https://www.amazon.com/Geser-\%D0\%92uryat-heroic-Khundaeva-Ye-ebook/dp/B0752T4HKB

Neklyudov S. Yu. Geroicheskiy epos mongol'skikh narodov. Moscow, 1984

Odigon S. Abai Geser — Tibetan. http://buryatmongol.org/epic-of-king-gesar-translation-by-sarangerel-odigon-2 Plumley D. Kray Gesera: Sbornik Statey i Materialov, ch. 2. Ulan Ude, 1996, p. 20-21. 381-401.

Rinchindorji. Mongolian-Turkic Epics: Typological Formation and Development//Oral Tradition 16.2, 2001, p.

Rudnev A. D. A Buriat Epic (Kha Oshir the son of Khan Bugdur Khan)// Mémoires de la Société Finno-Ugrienne

\section{2,1924 , p. 238-49.}

Schmidt I. J. Die Thaten Bogda Gesser Chans. St. Petersburg, 1839.

Sharakshinova N. O. Gersoicheskiy epos o Gesere. Irkutsk, 1969.

Shoolbraid G.M.H. The Oral Epic of Siberia and Central Asia. Bloomington, Indiana University Press, 1975.

Wallace Z. Gesar! The Epic Tale of Tibet's Great Warrior-King. Berkeley, 1991.

Zeitlin, I. Gessar Khan: A Legend of Tibet. Varanasi, 2003.

Zhamtsarano Ts. Zh. Alamzhi Mergen (bylina): Obraztsy narodnoy slovensnosti mongol'skikh" plemen"m tekstsy v. 1. ch. 1. Proizvedeniya narodnoy solesnosti buryat". Peterburg, 1913.

Zhamtsarano Ts. Zh. Ayduray Mergen i Irensey: Obraztsy narodnoy slovensnosti mongol'skikh" plemen", tekstsy v. 1. ch. 2. Peterburg, 1914.

Zhamtsarano, Ts. Zh. "Kha-Oshir Khubun": Obraztsy narodnoy slovensnosti mongol'skikh" plemen”, tekstsy v. 1. ch. 2. Peterburg, 1918.

Zhamtsarano, Ts. Zh. "Epicheskie provizvedeniya ekhirit-bulagatov: Geser-Bogdo, Epopeya, Obraztsy narodnoy slovensnosti mongol'skikh" plemen", tekstsy v. 2. ch. 1-2. Peterburg, 1930. 